\title{
Philosophiques
}

\section{Note de la rédaction}

Volume 11, numéro 2, octobre 1984

Égalité, justice et différence

URI : https://id.erudit.org/iderudit/203260ar

DOI : https://doi.org/10.7202/203260ar

Aller au sommaire du numéro

Éditeur(s)

Société de philosophie du Québec

ISSN

0316-2923 (imprimé)

1492-1391 (numérique)

Découvrir la revue

Citer ce document

(1984). Note de la rédaction. Philosophiques, 11(2), 335-335.

https://doi.org/10.7202/203260ar

Ce document est protégé par la loi sur le droit d'auteur. L'utilisation des services d'Érudit (y compris la reproduction) est assujettie à sa politique d'utilisation que vous pouvez consulter en ligne.

https://apropos.erudit.org/fr/usagers/politique-dutilisation/
Cet article est diffusé et préservé par Érudit.

Érudit est un consortium interuniversitaire sans but lucratif composé de l’Université de Montréal, l'Université Laval et l'Université du Québec à Montréal. Il a pour mission la promotion et la valorisation de la recherche. https://www.erudit.org/fr/ 


\section{ÉGALITÉ, JUSTICE ET DIFFÉRENCE}

\section{NOTE DE LA RÉDACTION}

Dans notre numéro précédent (Vol. XI, numéro 1, Avril 1984), nous avons présenté à nos lecteurs les quatre premiers d'une série de neuf textes produits par les membres d'une équipe de recherche travaillant au département de philosophie de l'Université de Montréal, sur le thème général de Égalité, justice et différence. Nous publions ici les cinq autres textes de la série. 